\title{
Data report: stress orientations from borehole breakouts, IODP Expedition 308, Ursa area, Mississippi Fan, Gulf of Mexico'
}

\author{
J. Casey Moore, ${ }^{2}$ Gerardo J. Iturrino, ${ }^{3}$ Peter B. Flemings, ${ }^{4}$ and Derek E. Sawyer ${ }^{4}$
}

\section{Chapter contents}

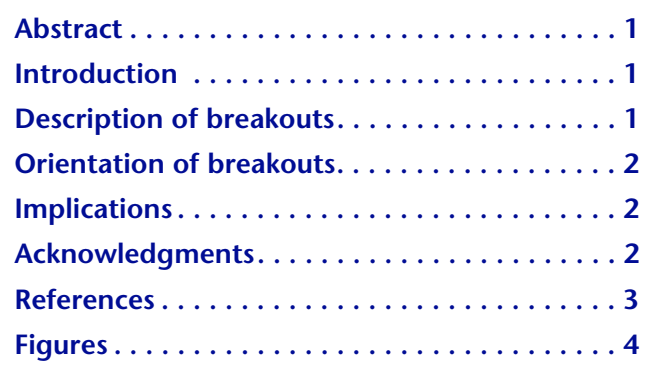

${ }^{1}$ Moore, J.C., Iturrino, G.J., Flemings, P.B., and Sawyer, D.E., 2009. Data report: stress orientations from borehole breakouts, IODP Expedition 308, Ursa area, Mississippi Fan, Gulf of Mexico. In Flemings, P.B., Behrmann, J.H., John, C.M., and the Expedition 308 Scientists, Proc. IODP, 308: College Station, TX (Integrated Ocean Drilling Program Management International, Inc.). doi:10.2204/iodp.proc.308.212.2009

2Earth and Planetary Sciences, University of California Santa Cruz, Santa Cruz CA 95064, USA. cmoore@pmc.ucsc.edu

${ }^{3}$ Borehole Research Group, Lamont-Doherty Earth Observatory of Columbia University, Palisades NY 10964, USA.

${ }^{4}$ John A. and Katherine G. Jackson School of Geosciences, University of Texas, Austin TX 78712, USA.

\section{Abstract}

Borehole failures are a conspicuous feature of the logging-whiledrilling resistivity images at Integrated Ocean Drilling Program Sites U1322 and U1324. Failures appear as irregular zones of low resistivity on opposite sides of the well bore (resembling traditional breakouts) and also as zones of high resistivity flanked by narrower low-resistivity intervals. The failures show a consistent east-west trend at both sites and with depth in each. The inferred $S_{H \text { min }}$ directions are $85^{\circ}-265^{\circ}$ and $91^{\circ}-271^{\circ}$, respectively, at Sites U1322 and U1324. $\mathrm{S}_{\mathrm{H} \max }$ at Sites U1322 and U1324 is oriented subparallel to the overall southerly slope of the Gulf of Mexico slope in this region. At Site U1322, $\mathrm{S}_{\mathrm{Hmin}}$ is perpendicular to en echelon extensional fractures along the margin of a submarine landslide.

\section{Introduction}

Borehole breakouts were recognized during the initial analysis of logging-while-drilling (LWD) imaging logs from Integrated Ocean Drilling Program (IODP) Expedition 308 (see the "Site U1322" chapter). Elsewhere breakouts have been documented from convergent margins during the Ocean Drilling Program (ODP) (Goldberg and Janik, 2006; McNeill et al., 2004). The breakouts from Expedition 308 cores are a first occurrence, encountered during IODP drilling, from a passive continental margin. The site report notes that the breakouts are oriented approximately east-west. This data report provides a more extensive examination of the breakouts from the Ursa region on the Mississippi Fan (Fig. F1). The analysis includes quantification of the azimuthal and depth distribution of the breakouts and was conducted using GMIImager software, produced by Geomechanics International.

\section{Description of breakouts}

Borehole breakouts are compressional failures of the borehole wall produced in a vertical well by near-borehole amplification of in situ horizontal stresses. For a concise review of breakout formation and further references, see Goldberg and Janik (2006). Breakouts occur on opposite sides of the borehole along a direction parallel to the minimum far-field stress. In a vertical well, they generally occur at the azimuth of the minimum horizontal stress 
$\left(\mathrm{S}_{\mathrm{Hmin}}\right)$ and perpendicular to the maximum horizontal stress $\left(\mathrm{S}_{\mathrm{Hmax}}\right)$. These borehole failures are generated by compressive failure of the borehole wall and result in its enlargement in the $S_{\mathrm{Hmin}}$ direction. In resistivity images, the failed areas normally appear as low-resistivity zones because of enlargement and/or fracturing of the borehole. Salt water in the borehole is more conductive than sediment; where the borehole is enlarged, the resistivity imaging tool sees higher conductivity or lower resistivity (Fig. F2A). The resistivity imaging tool has a resolution of $2-3 \mathrm{~cm}$ horizontally and $3-5 \mathrm{~cm}$ vertically at the shallow level of investigation $(2-3 \mathrm{~cm})$ beyond the tool diameter (shipboard Schlumberger Engineers, pers. comm.).

The occurrence of breakouts at shallow depths in muddy sediments may seem surprising. Muds are typically considered highly anelastic (viscous) and thus would be expected to flow rather than fracture. The borehole failures we discuss must have formed quickly, within minutes of cutting of the hole. Penetration rates are typically $\sim 30 \mathrm{~m} / \mathrm{h}$ and the resistivity imaging tool is located $\sim 3 \mathrm{~m}$ above the bit. Drilling of the borehole rapidly removes the lateral confining stress of the sediment, replacing it with a hydrostatic fluid pressure at the borehole wall. Thus, the borehole failures can be approximated by the low confining stress triaxial experiments carried out on the cores from the Ursa region (Urgeles et al., 2007). It is reasonable to interpret these features as borehole breakouts.

The breakouts shown in Figure F2A (100-110 m) are typical of those documented in resistivity images from other ODP and IODP holes. Other breakouts at IODP Site U1322, developed at 190-200 m, are more complicated and characterized by a high-resistivity zone flanked by zones of low resistivity (Fig. F2B). These latter images may represent an incipient failure mode that leaves a ridge of high-resistivity sediment between adjacent highly fractured zones (the flanking low-resistivity areas). The zone of highresistivity sediment may represent a block of more intact material caught between conjugate fractures and bulging into the borehole in the $\mathrm{S}_{\mathrm{Hmin}}$ direction. The high-resistivity signal results from sediment extruded closer to the resistivity tool. These highresistivity features are located on opposite sides of the borehole and show azimuths consistent with the more typical breakouts above. The high-resistivity zones are narrower and straighter than the typical breakouts. This geometry is consistent with an incipient stage of failure, which could evolve to the broader more irregular low-resistivity breakout with spallation of the central high-resistivity block (Moos et al., 2007).

\section{Orientation of breakouts}

Although the breakouts occur in pairs on opposite sides of the borehole, we have projected occurrences in the western half of the borehole to the eastern half (following the convention of the GMI-Imager software). Hence, all values range between $0^{\circ}$ and $180^{\circ}$ and are plotted as a single histogram. The histogram for Hole U1322A is particularly symmetrical and shows little downhole variation in azimuth $\left(\right.$ mean $=85^{\circ}$, standard deviation $\left.=9.3^{\circ}\right)($ Fig. F3). The breakouts were less well developed in IODP Hole U1324A but show the same general east-west orientation (mean azimuth $=91^{\circ}$, standard deviation $=$ $15.6^{\circ}$ ) (Fig. F4). According to accepted quality ranking criteria (Zoback and Zoback, 1991) the breakouts in Hole U1322A are of highest or " $\mathrm{A}$ " quality, whereas breakouts in Hole U1324A are of "B" quality. Although the downhole occurrence of the breakouts is concentrated into particular zones, a cursory inspection indicates no consistent correlations to lithologic or log properties. For example, the breakouts appear to occur more often within the mass transport deposits at Site U1322 but not at Site U1324.

Breakout orientation represents $S_{\mathrm{Hmin}}$ at $85^{\circ}-265^{\circ}$ and $91^{\circ}-271^{\circ}$, respectively, at Sites U1322 and U1324. $\mathrm{S}_{\mathrm{Hmin}}$ vectors for each hole are plotted on the UrsaMars region bathymetric map (Fig. F1).

\section{Implications}

Because the LWD resistivity imaging tool is located $\sim 3 \mathrm{~m}$ above the bit and the borehole is drilled at $20-30 \mathrm{~m} / \mathrm{h}$, the breakouts must form a few minutes after drilling in order to be imaged. Thus, the breakouts represent a rapid, typically brittle failure mode and measure current in situ stress. Widespread gravitational failure in the Ursa region drilled by IODP (Sawyer et al., 2007) indicates that the maximum principal stress is vertical, which is typical of passive continental margins. Thus, $\mathrm{S}_{\mathrm{H} \max }$ and $\mathrm{S}_{\mathrm{H} \min }$ at Sites U1322 and U1324 are the intermediate and minimum principal stresses, respectively. The approximately north-south $S_{H \max }$ at Sites U1322 and U1324 is subparallel to the overall southward-dipping regional slope of the Gulf of Mexico. At Site U1322, $\mathrm{S}_{\mathrm{Hmin}}$ is perpendicular to en echelon extensional fractures along the margin of a nearby submarine landslide.

\section{Acknowledgments}

This research used samples and data provided by the Integrated Ocean Drilling Program (IODP). We ac- 
knowledge IODP for providing the platform and personnel to accomplish LWD during Expedition 308, and also the U.S. Science Support Program (USSSP) for support to conduct the research both during Expedition 308 and postcruise. We acknowledge Shell Oil and its partners for access to the three-dimensional seismic data that was used for Figure F1 and allowed investigation of the subsurface geology. Landmark Graphics Corporation and GeoMechanics International, respectively, provided the software to analyze the seismic data and borehole failure orientations. We thank Dan Moos for his timely and careful review of this report.

\section{References}

Goldberg, D., and Janik, A., 2006. Data report: stress orientation in gas hydrate-bearing sediments near Hydrate Ridge: evidence from borehole breakouts observed from logging-while-drilling resistivity images. In Tréhu, A.M., Bohrmann, G., Torres, M.E., and Colwell, F.S. (Eds.), Proc. ODP, Sci. Results, 204: College Station, TX (Ocean Drilling Program), 1-14. doi:10.2973/ odp.proc.sr.204.108.2006

McNeill, L.C., Ienaga, M., Tobin, H., Saito, S., Goldberg, D., Moore, J.C., and Mikada, H., 2004. Deformation and in situ stress in the Nankai accretionary prism from resistivity-at-bit images, ODP Leg 196. Geophys. Res. Lett., 31(2):L02602. doi:10.1029/2003GL018799
Moos, D., Wilson, S., and Barton, C.A., 2007. Impact of rock properties on the relationship between wellbore breakout width and depth. In Eberhardt, E., Stead, D., and Morrison, T. (Eds.), Rock Mechanics: Proceedings of the 1st Canada-US Rock Mechanics Symposium, Vancouver, Canada, 27-31 May 2007: London (Taylor \& Francis Group), 1677-1683.

Sawyer, D.E., Flemings, P.B., Shipp, R.C., and Winker, C.D., 2007. Seismic geomorphology, lithology, and evolution of the late Pleistocene Mars-Ursa turbidite region, Mississippi Canyon area, northern Gulf of Mexico. AAPG Bull., 91(2):215-234. doi:10.1306/08290605190

Urgeles, R., Locat, J., Flemings, P., Behrmann, J., John, C., and the Expedition 308 Scientific Party, 2005. Triggering mechanisms of slope instability processes on the Gulf of Mexico continental slope: preliminary results from IODP Expedition 308. Eos, Trans. Am. Geophys. Union, 86(52)(Suppl.):OS24A-06. (Abstract) http:// www.agu.org/meetings/fm05/waisfm05.html

Zoback, M.D., and Zoback, M.L., 1991. Tectonic stress field of North America and relative plate motions. In Slemmons, D.B., Engdahl, E.R., Zoback, M.D., and Blackwell, D.D. (Eds.), Neotectonics of North America: Boulder, CO (Geol. Soc. Am.), 339-366.

Initial receipt: 1 July 2008

Acceptance: 24 June 2009

Publication: 1 September 2009

MS 308-212 
Figure F1. Sidelit bathymetry (meters below sea level) of Ursa region mapped from three-dimensional seismic data. Illumination is from the northwest. TLP $=$ tension leg platform. $\mathrm{CI}=$ contour interval.

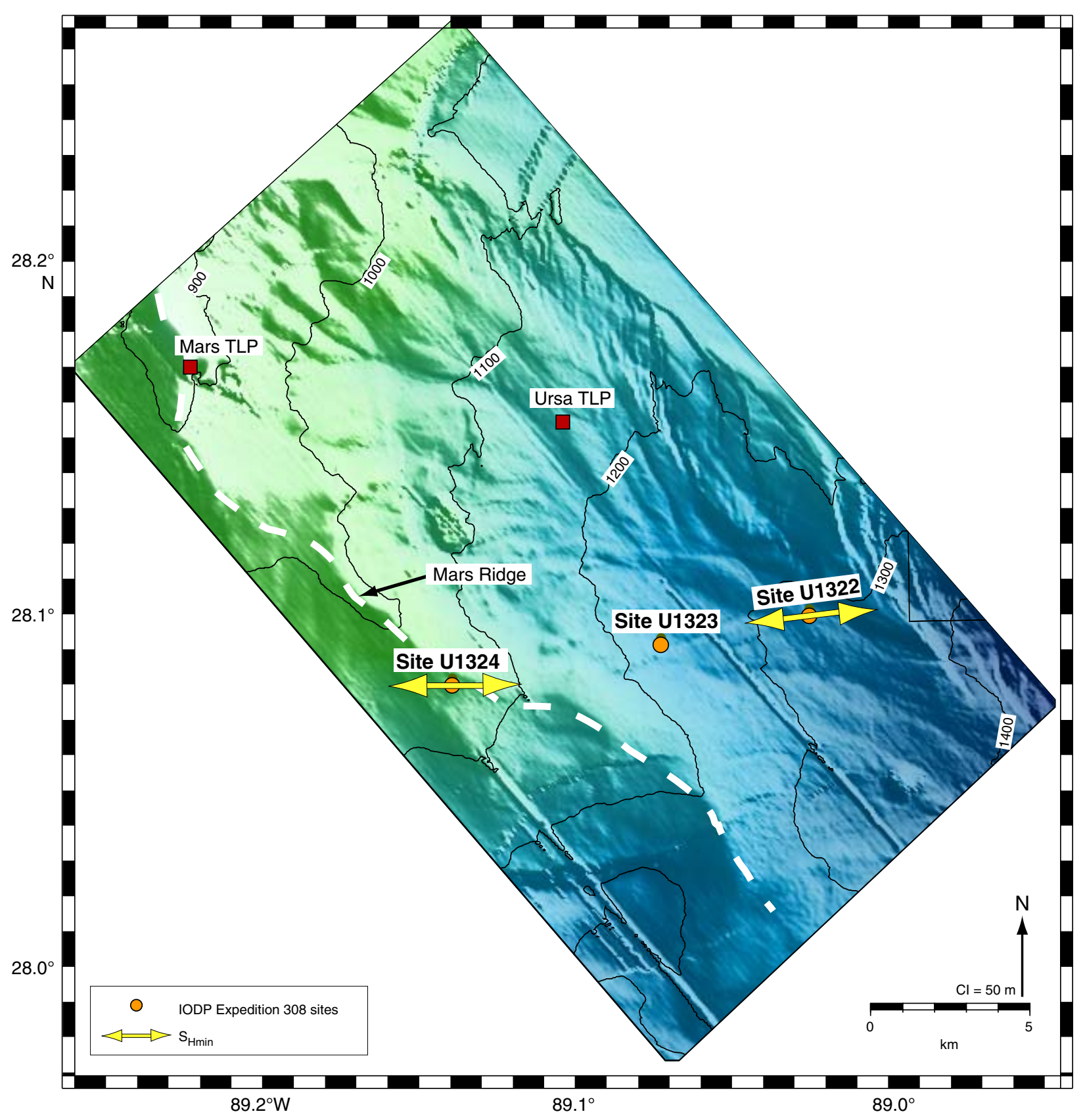


Figure F2. Breakouts in resistivity images acquired while drilling Hole U1322A. A. Well-developed breakouts from 100 to $110 \mathrm{mbsf}$ are characterized by conspicuous zones of low resistivity. B. Breakouts from 190 to 200 mbsf are represented by a central high-resistivity zone flanked by low-resistivity intervals. Breakouts are oriented similarly to those in A but are narrower and straighter, perhaps representing an incipient stage of failure with a central high-resistivity zone flanked by external fractures. The high-resistivity zone may represent a central extruded block flanked by conjugate fractures.

\section{A}

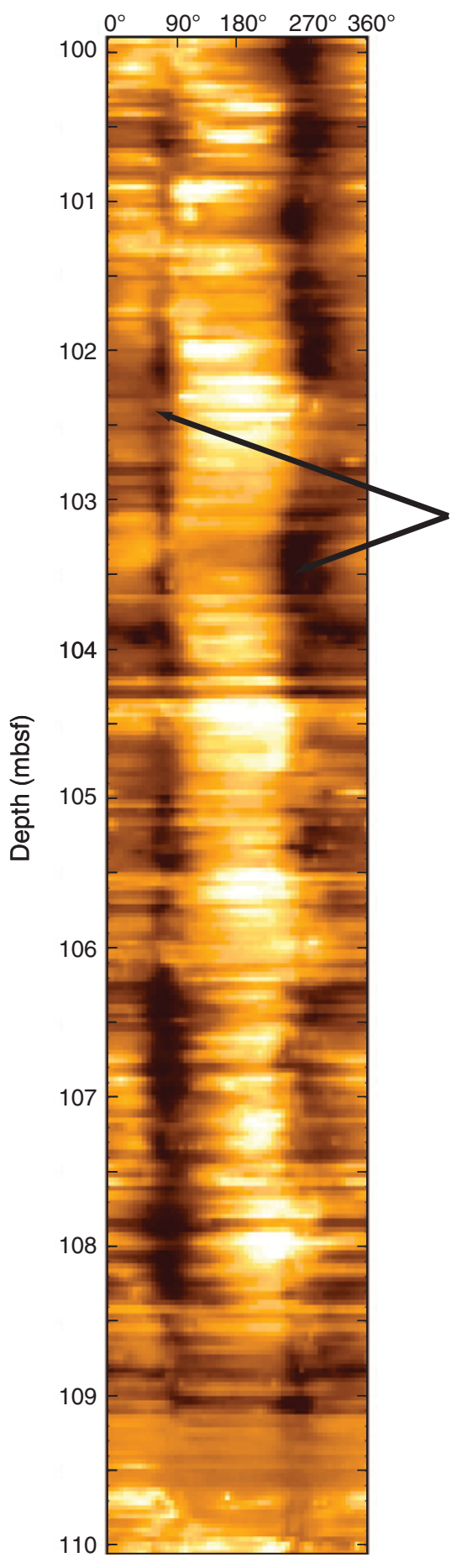

B

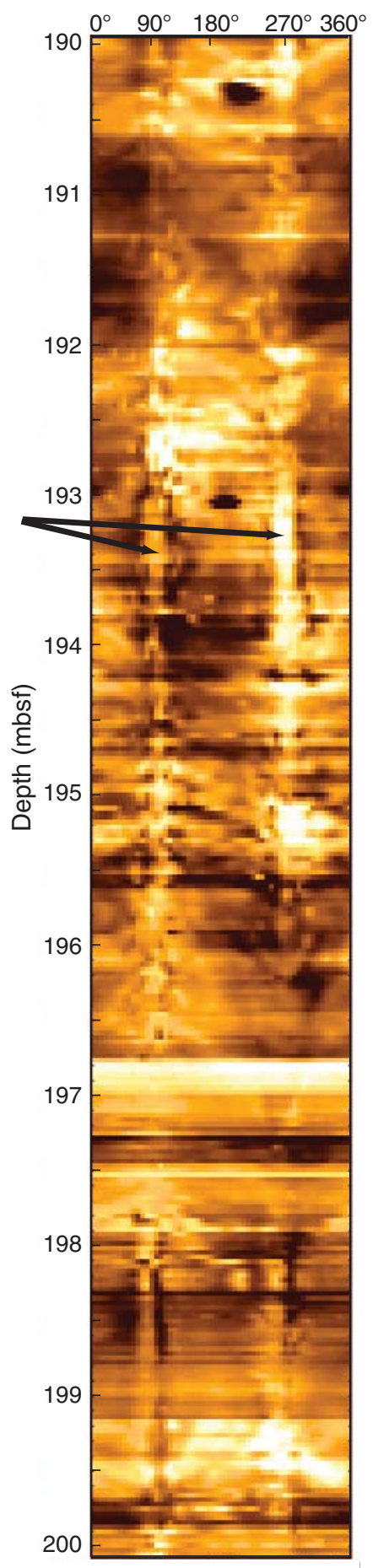

Low

Breakouts

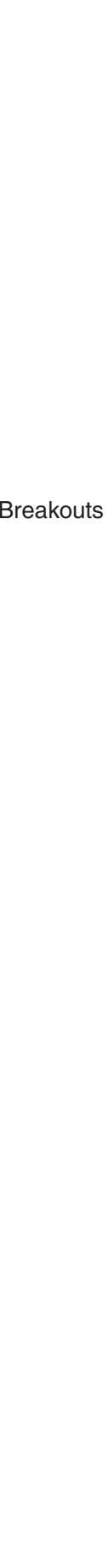

Resistivity

High 
Figure F3. Breakout orientations, Site U1322. A. Histogram of all breakout azimuths. B. Breakout azimuths with depth.
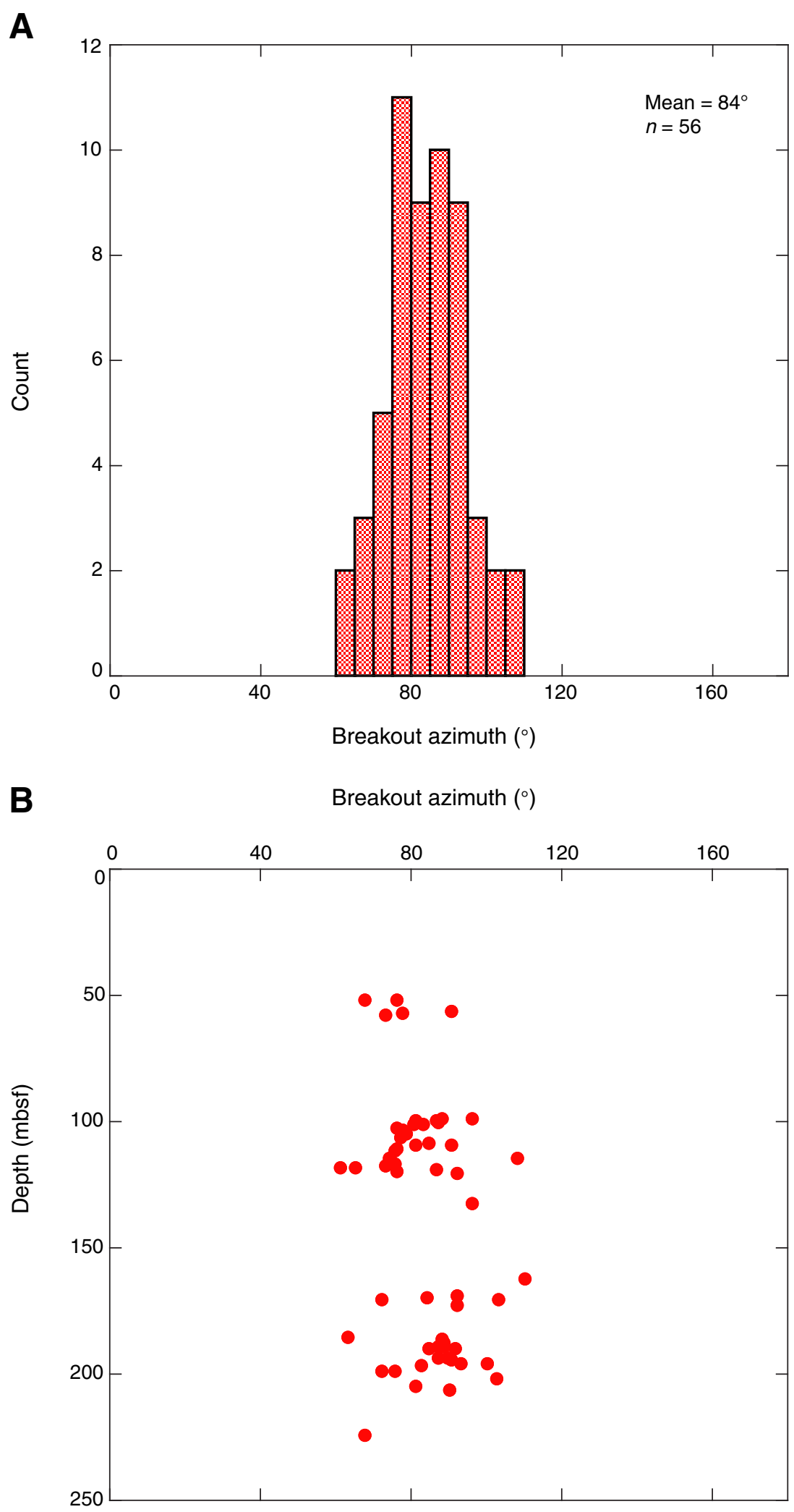
Figure F4. Breakout orientations, Site U1324. A. Histogram of all breakout azimuths. B. Breakout azimuths with depth.

A

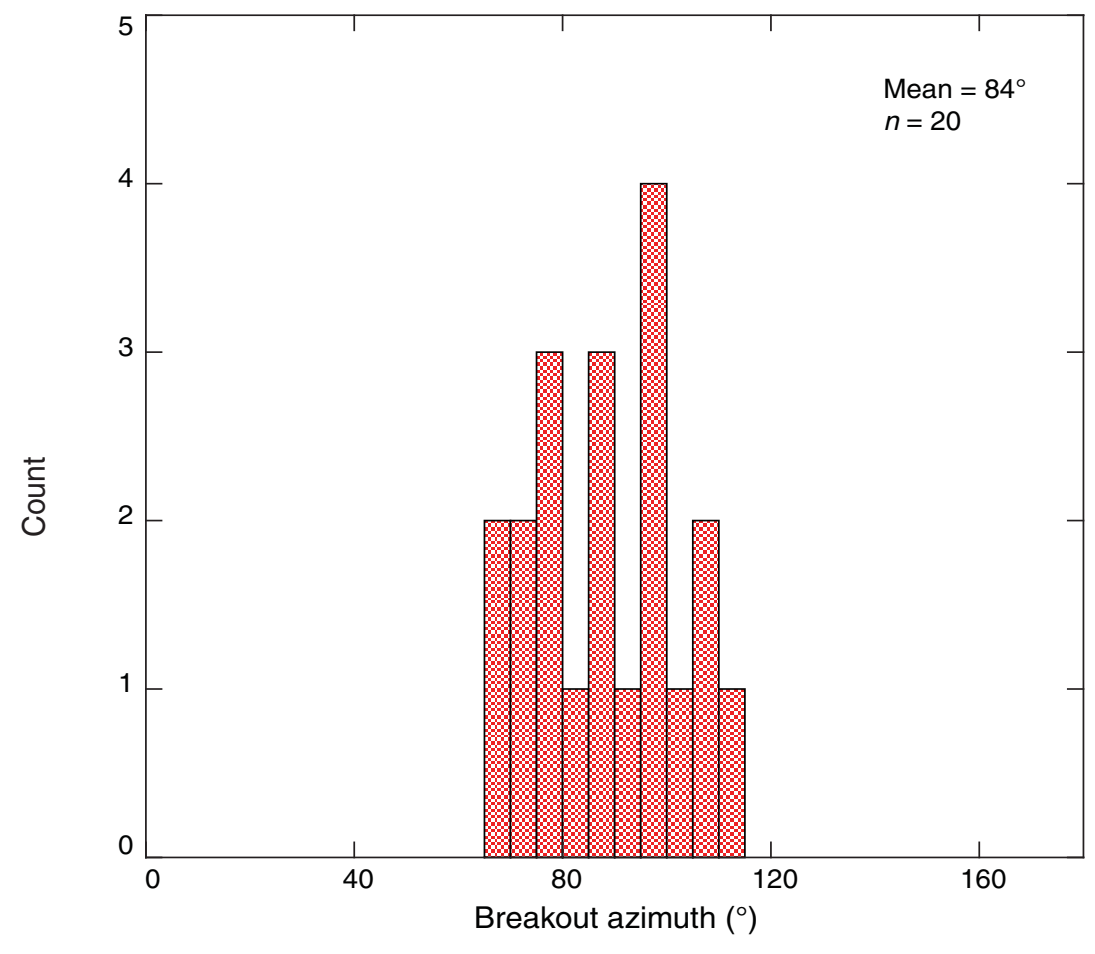

B

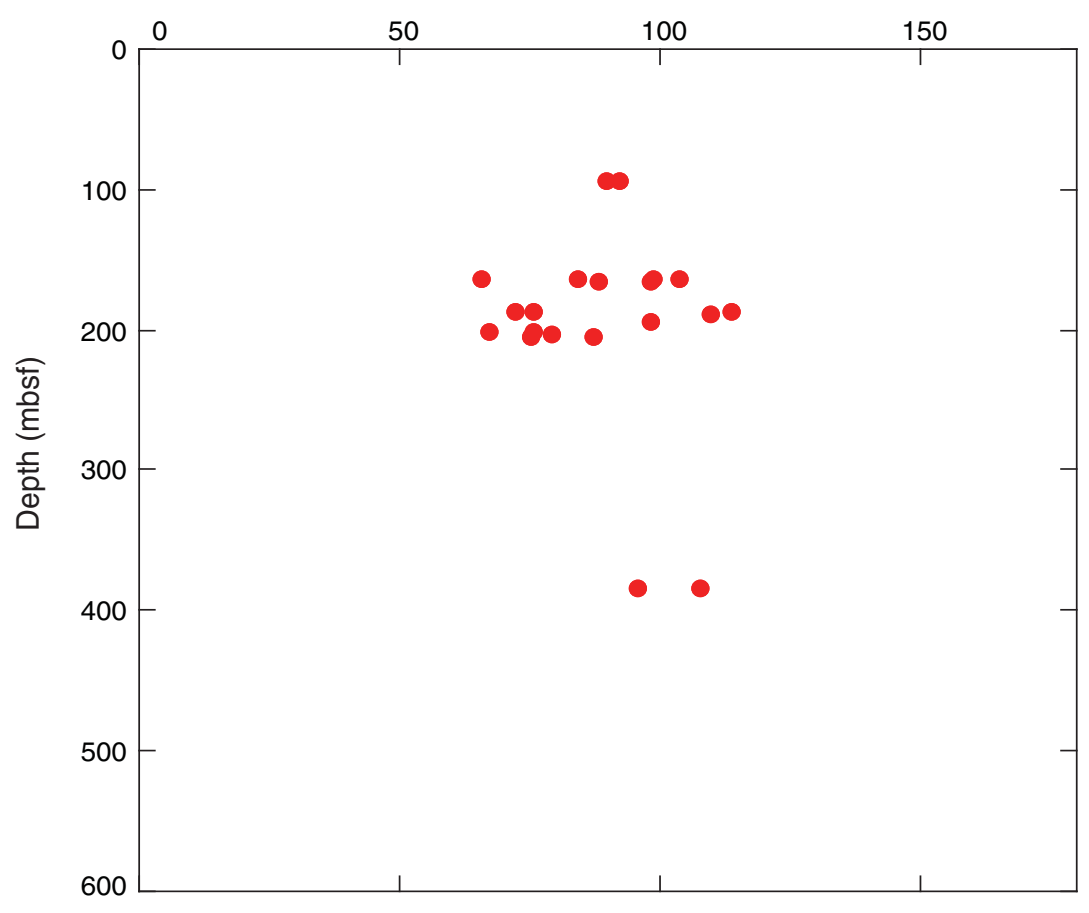

